\title{
Domains of Technological Pedagogical and Content Knowledge: Factor Analysis of Indonesian In-Service EFL Teachers
}

\section{Lantip Diat Prasojo}

Prof., Universitas Negeri Yogyakarta, Indonesia, lantip@uny.ac.id

\section{Akhmad Habibi}

Universitas Jambi, Indonesia, akhmad.habibi@unja.ac.id

\section{Amirul Mukminin}

Universitas Jambi, Indonesia, amirul.mukminin@unja.ac.id

\section{Mohd Faiz Mohd Yaakob}

Universiti Utara Malaysia. Malaysia, mohd.faiz@uum.edu.my

This study aims at developing and validating the proposed survey instrument and elaborating how Indonesian English as Foreign Language (EFL) in-service teachers perceive their TPACK. A total number of 573 in-service EFL teachers completed a 28 -item survey instrument. A pool of the survey instrument was assessed through content and face validity mainly using Content Validity Index (CVI) involving ten educational technology and policy experts. Through Exploratory Factor Analysis (EFA) and Confirmatory Factor Analysis (CFA), seven factors of TPACK were reported. The results indicate that Indonesian inservice EFL teachers lack technological knowledge, but they perceive that they have a sufficient level of pedagogical knowledge. Differences in perceptions were also found according to gender and age.

Keywords: TPACK, factor analysis, English teachers, technology, teaching

\section{INTRODUCTION}

Various reported problems have been highlighted regarding in-service teacher training programs in Indonesia and other developing countries. However, one of the most important concerns is the teachers' skills and knowledge in teaching in the era of technology. Teachers in this era face many challenges, and one of the greatest challenges is the need to reform teaching approaches ways to fulfill the needs of the current generation of students. This generation is categorized as millennial (Howe \& Strauss, 2000), who cannot be separated from the use of technology in their daily lives,

Citation: Prasojo, L. D., Habibi, A., Mukminin, A., \& Yaakob, M. F. M. (2020). Domains of Technological Pedagogical and Content Knowledge: Factor Analysis of Indonesian In-Service EFL Teachers. International Journal of Instruction, 13(4), 593-608. https://doi.org/10.29333/iji.2020.13437a 
such as laptops, smartphones, personal computers, and tablets as well as the Internet. Teaching this kind of students is a highly complex process that requiresvarious kinds of knowledge where the task is very demanding (Watt \& Richardson 2012). Nowadays, it is not adequately accepted when teachers only have a good level of pedagogical and content knowledge for a subject (Luik, Taimalu, \& Suviste, 2018). The knowledge of how to use technology in teaching is also a key issue in teaching the Millennial. The effective use of digital technology as has been reported in many empirical studies in education including in Indonesian (Habibi, Yusop, \& Razak, 2019a).

There have been many studies conducted from the education community in the TPACK framework since it was first introduced by Mishra and Koehler (2006). The TPACK framework provide teacher educators with a new approach to conceptualize and assess pre-service and in-service teachers' knowledge and abilities in integrating various kinds of technology into their teaching activities. This is a very important thing in teacher education context where with the rapid growth of technology in current K-12 classrooms, the frameworks to measure teachers' knowledge like TPACK are required to support teachers when they learn to integrate technologies that are widely provided for learning.

Survey is among the most popular approach in assessing TPACK in a context or setting (Koehler, Shin, \& Mishra, 2012). It provides an opportunity to assess TPACK in a great number of audiences (Graham, Borup, \& Smith, 2012). Some survey regarding TPACK have been reported valid and reliable (Koehler et al., 2012). However, some issues associated with TPACK surveys emerged, such as limited clarity between TPACK constructs boundaries (Archambault \& Barnett, 2010). Thus, the available TPACK surveys sometimes have been unsuccessful for an independent assessment of each TPACK construct. The items are also general: while this increases their applicability, the items can have more bias and misrepresented. Context and setting of TPACK items are also important consideration. For EFL teaching in Indonesian context for in-service teachers, the validation study of a self-assessment TPACK scale can be very beneficial (Habibi, Yusop, \& Razak, 2019a). Therefore, this study is proposed to develop and validate a scale for Indonesian EFL in-service teachers TPACK. In addition the perception examination the TPACK domains and differences in terms of gender and age were also reported.

\section{LITERATURE REVIEW}

\section{TPACK}

A country requires professional and competent teachers. Educating teachers, in-service or pre-service, is a large concern. It is difficult to define knowledge of teachers within $21^{\text {st }}$ century education requirement where the use of technology is massive. No concuss emerges indicating how teacher knowledge should be understood and what teachers should have in teaching (Goodwin \& Kosnik 2013; Murray, 2001).. Shulman (1986) introduced a framework focusing on the content knowledge of the teacher, which known as Pedagogical and Content Knowledge (PCK) which represents content and pedagogy linked. There are three focused areas in his model: pedagogical knowledge (PK), 
content knowledge (CK) and pedagogical content knowledge (PCK). PCK consists of knowledge of teaching strategies for a specific subject in different kinds of contexts and knowledge about structures, illustrations, and examples of content in teaching to be more understandable (Shulman 1986).

Voss, Kunter, \& Baumert (2011) improved Shulman's (1986) PK by including psychological domain become pedagogical/psychological knowledge (PPK) defining the classroom as a social group. The framework was comprised of three areas: CK, PPK, and PCK. To complete CK and PCK, knowledge of classroom management, teaching methods, classroom assessment, and the learning processes as well as individual characteristics of students were also included. The framework, PPK proposed by Voss et al. (2011) was extended by other researchers (e.g. Grossman, 1995; Paulick, De Miranda, \& Shin, 2016; Phillips, Großschedl, Harms, \& Möller, 2009). For example, Grossman (1995) and Phillips et al. (2009) extended a fourth dimension which included contextual knowledge. In this framework, they informed model circles that includedcontent, pedagogy and context domain resulting in the establishment of seven areas of knowledge: CK, PK, PCK, context knowledge, content in context knowledge, pedagogical context and PCK in context (Grossman, 1995; Phillips et al., 2009).

All elaborated models were established based on Shulman's (1986) PCK framework, reported by different researchers. As the technology advancement has changed rapidly, Mishra and Koehler (2006) established a new framework that was also based on Shulman's (1986) model where they extended technology to content and pedagogy. Mishra and Koehler (2006) reported that studying how technology is pedagogically used to teach content is very important in the $21^{\text {st }}$-century education. They called their framework TPACK comprising of seven domains pictured as a Venn diagram with overlapping circles. The three circles in the TPACK framework explain core domains of teacher knowledge:CK, Technology Knowledge (TK), and PK. Meanwhile, the four overlapping domains elaborate on the integration of the three circles (Mishra \& Koehler 2006). TK is teachers' understanding of technologies that could be implemented in education. PK is teachers' understanding of the conditions required for learning and common approaches to and teaching method. Meanwhile, CK is teachers' understanding of the subject matter (Mishra \& Koehler, 2006). TCK is knowledge of subject matter integrated through technology; TPK is knowledge of integrating technology for teaching method; PCK knowledge of methods of teaching in different contexts of subjects; TPACK is knowledge of integrating technology for teaching methods in different subject contexts. 


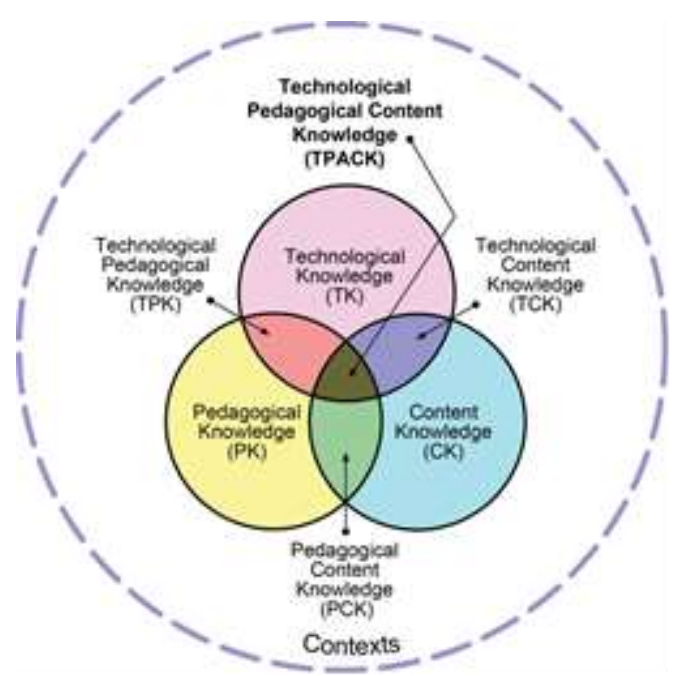

Figure 1

TPACK Framework, Right Free (source: http://tpack.org/)

Graham et al. (2012) stated that in the original TPACK framework, technology in general term was the object. However, digital technology was emphasized to become the main object for later TPACK-based studies. For example, Angeli and Valenidas (2009) added ICT to the framework with the term "ICT-TPCK"; Lee and Tsai (2010) used World Wide Web (WWW) and TPACK-W as the term. It is important to narrow technology definition for the clarity of research. Due to the high-frequency use of ICT in Indonesian teaching (Habibi et al., 2019), we applied this term in our study. We define ICT as a broadly accepted term for all devices, such as a laptop, smartphone, projector, and an I Pad that help people to have interaction in the digital world. Since teachers often fail to integrate technology into their instructional activities to teach the content of the earning material (Teo, Sang, Mei, \& Hoi, 2018), this study used TPACK to highlight Indonesian in-service EFL teachers' ICT integration.

\section{Instruments for assessing TPACK}

Many instruments of teachers' TPACK have been established to examine the implementation of technology integration policy, curriculums, and the effectiveness of technology integration training. The first established and probably the most frequently cited instrument was developed by Schmidt, Baran, Thompson, Mishra, Koehler, and Shin (2009) intended to assess pre-service primary school teachers. They reported the validity of their instrument using content validity and factor analysis from survey data resulting in 7 factors, TK, PK, CK, PCK, TCK, TPK, and TPACK. Many researchers using Schmidt et al. (2009) failed to find all seven factors of the knowledge when validating adaptations of Schmidt et al. (2009) survey (e.g. Bostancioğlu \& Handley, 2018; Chai, Koh, Tsai, \& Tan, 2011; Koh, Chai, \& Tsai, 2010; Luik et al., 2018; Shinas, Yilmaz-Ozden, Mouza, Karchmer-Klein, \& Glutting, 2013). From all the areas of 
knowledge hypothesized to underpin Schmidt's et al. (2009) TPACK, PK frequently failed to be identified as a separate factor. However, Baser, Kopcha, and Ozden (2016) reported that their TPACK examination resulting in 7 factors (Table 1).

Table 1

TPACK Factors from Previous Studies

\begin{tabular}{|c|c|c|c|c|}
\hline Study & $\begin{array}{l}\text { Number of } \\
\text { samples }\end{array}$ & $\begin{array}{l}\text { Number } \\
\text { of items }\end{array}$ & $\begin{array}{l}\text { Number } \\
\text { of factors }\end{array}$ & Names of factors \\
\hline $\begin{array}{l}\text { Schmidt et al. } \\
\text { (2009) }\end{array}$ & $\mathrm{N}=124$ & $\begin{array}{l}47 \text { of } 75 \\
\text { items }\end{array}$ & 7 & TK, PK, CK, PCK, TCK, TPK, TPACK \\
\hline Chai et al. (2010) & $\begin{array}{l}\mathrm{N}=439 \\
\text { and } \mathrm{N}= \\
365\end{array}$ & $\begin{array}{l}18 \text { of } 18 \\
\text { items }\end{array}$ & 4 & TK, CK, PK, TPACK \\
\hline Koh et al. (2010) & $\mathrm{N}=1885$ & $\begin{array}{l}28 \text { of } 29 \\
\text { items }\end{array}$ & 5 & $\begin{array}{l}\text { TK, CK, Knowledge of Pedagogy/KP, } \\
\text { Knowledge of Teaching with Technology/KTT, } \\
\text { Knowledge of Critical Reflection/KCR }\end{array}$ \\
\hline $\begin{array}{l}\text { Shinas et al. } \\
(2013)\end{array}$ & $N=365$ & $\begin{array}{l}46 \text { of } 447 \\
\text { items }\end{array}$ & 8 & $\begin{array}{l}\text { TK, PK, Mathematical Content } \\
\text { Knowledge/CKM, Science Content } \\
\text { Knowledge/CLS, Literacy Content } \\
\text { Knowledge/CKL, Social Science Content } \\
\text { Knowledge/CKSS, TPK, TPACK }\end{array}$ \\
\hline $\begin{array}{l}\text { Baser et al. } \\
\text { (2016) }\end{array}$ & $\begin{array}{l}\mathrm{N}=174 \\
\text { and } \mathrm{N}= \\
204\end{array}$ & $\begin{array}{l}39 \text { of } 50 \\
\text { items }\end{array}$ & 7 & TK, PK, CK, PCK, TCK, TPK, ТPACK \\
\hline Luik et al. (2018) & $\mathrm{N}=413$ & $\begin{array}{l}51 \text { of } 103 \\
\text { items }\end{array}$ & 3 & Technology, Pedagogy, Content \\
\hline $\begin{array}{l}\text { Bostancioğlu and } \\
\text { Handley (2018) }\end{array}$ & $\mathrm{N}=542$ & $\begin{array}{l}36 \text { of } 45 \\
\text { items }\end{array}$ & 6 & TK, CK, ТPК, TCK, РCK, ТРCK \\
\hline
\end{tabular}

For language teaching, Chai'set al. (2013) was the first instrument developed with the specific purposes of examining TPACK among teachers of Chinese as a second language in Singapore, the entire content-related items of Schmidt's et al. (2009) TPACK were adapted; however, only 4 factors were reported to be valid. On the other hand, Baser et al. (2016) established a new instrument of TPACK for pre-service English language teachers in Turkey: they did a consultation session to meet national and international standards focusing on the technology integration for English language teaching. On the basis of this consultation, they generated an item pool and reviewed by a panel of experts (Habibi, Yusop, Razak, 2019b). Bostancioğlu and Handley (2018) also developed an instrument to measure pre-service English teachers TPACK in Turkey through content validity involving 36 international experts. EFA and Confirmatory Factor Analysis (CFA) were also part of the validation process for a 36-item survey reported in the final conclusion.

There is no reported scale of the TPACK framework suitable for all contexts and settings: research object, subjects, and countries. Different results have also been reported regarding demographic information which correlates to TPACK domains. Therefore, more studies of TPACK in different settings are still required (Koh et al. 2010). This study was conducted to: (1) develop and validate the TPACK scale in Indonesian context of in-service EFL teachers; (2) elaborate the perceptions of TPACK 
by Indonesian in-service EFL teachers and (3) report TPACK differences in perceptions according to gender and age.

Technology integration in EFL teaching

The main purpose of this study was to develop a TPACK survey that examines Indonesian in-service EFL teachers' knowledge of using technology to teach EFL. The survey is a self-assessment for in-service teachers focusing on TPACK within the EFL content area. The need for such a survey is high. Even though some studies reported a successful development of valid and reliable EFL-specific survey (Baser et al., 2016; Bostancioğlu \& Handley, 2018), there has yet to be a valid and reliable TPACK survey developed for EFL teachers in a developing country such as Indonesia. English is included as a compulsory course in Indonesia, as well as other countries such as, Russia, Spain, Egypt, Malaysia, and Brazil (Crystal, 2003). A valid and reliable EFL-specific TPACK survey for a specific setting and context would give teacher educators a tool for the teacher assessment and their potential for technology integration in EFL teaching.

Technology is important in supporting EFL teaching for specific types of activities. For instance, computer-based learning to promote Computer Assisted Language Learning (CALL), social media such as Facebook to support learners to use language in a meaningful way (Kabilan, Ahmad, Abidin, 2010), WhatsApp, Telegram, Email, and Google Form to support communication, build social interaction, and tools for supervision in a pre-service teacher training program (Habibi, Mukminin, Riyanto, Prasojo, Sulitiyo, Sofwan, \& Saudagar, 2018). Computer-based communication tools can improve students' language skills by facilitating interaction between students and native English-speakers (Golonka, Bowles, Frank, Richardson, \& Freynik, 2014). Audio and video tools make students to have visual and auditory sources of learning used in real (Bernhardt, 2010). A survey like TPACK-EFL facilitates teacher educators a valid and reliable instrument addressing the unique pedagogical and technological strategies in education allowing EFL community to obtain betterment. Such a survey can be made into a translation into multiple languages and utilized to assess TPACK among a variety of teachers, in-service or pre-service, who teach and will teach English in the current time and in the future.

\section{METHOD}

This study was part of a research project that aimed at evaluating Indonesian in-service teachers' integration of technology during their teaching activities. Review of previous studies, the assessment of validity and reliability mainly through Content Validity Index (CVI) were done before the data collection. Two factorial analyses were done through EFA and CFA. The dataset can be accessed on DOI: 10.17632/fj467mmws8.1.

\section{Instrumentation}

The developing of the survey instruments consisted of several steps. Firstly, a pool of items was initiated as items from different studies (Baser et al., 2016; Bostancioğlu \& Handley, 2018; Schmidt et al. 2009). Forty-one items were formulated within the pool. We discussed the pool with five educational technology experts from Indonesia. As a 
result, 9 items were dropped due to its redundancy and unfitted context with Indonesian education. In this step, 31 items remained for the next process of the instrument validity. A panel of 10 experts from Indonesia, North Ireland, Hungary, and Malaysia; Four educational technologists, 3 Indonesian educational policy researchers, and 3 Ph.D. students majoring in educational technology and applied linguistics were willing to participate in a process of CVI rating the instruments for the relevance, clarity, and simplicity.

The attributes of the items were rated on a 4-point scale in the CVI process $(1=$ not relevant/not clear/ not simple to $4=$ very relevant/ very clear/ very simple (Lynn, 1986; Halek, Holle, \& Bartholomeyczik, 2017). The CVI was evaluated both at the item level (I-CVI) and scale level (S-CVI). The I-CVI was scored by facilitating a score of 3 or 4 to the experts that were divided by the total number of experts (Lynn, 1986). With a total of ten experts, the I-CVI should not be less than the value of .780 (Halek et al., 2017). Meanwhile, the acceptable value for the S-CVI is .800 (Halek et al., 2017). In the calculation process of the S-CVI, the average portion of the items on one scale rated 3 or 4 (average agreement by experts $=\mathrm{S}-\mathrm{CVI} / \mathrm{AVE}$ ) was conducted. Most of the score of the item of I-CVI and S-CVI exceeded the recommended threshold values; however, 2 items were excluded due to the low values of CVI. We translated the instruments from English to Indonesian language and Indonesian language to English through back to back translation (Behr, 2017) involving two experts in Indonesian-English translation. We consider the translation process to ensure that the respondents would fully understand the instruments written in their native.

After the face and content validity process, a pilot study was done with 100 Indonesian in-service EFL teachers. We allowed them to write comments about how they understood each item. Items that confused them or were misunderstood were revised. Additionally, Cronbach's alpha values were calculated in this process where it was found that no values were less than .700 (Pallant, 2016) as the cut off point for the data reliability. Two questions about the respondents' background (gender and age) were added to the questionnaire. The main data was collected from January 2018 to December 2018. We informed respondents that the participation in this study was voluntary, and they have right to reject filling in the survey form.

\section{Participants}

We distributed the survey instrument to 700 Indonesian in-service EFL teachers from 3 cities, Jambi, Palembang, and Yogyakarta. Six hundred and one teachers returned the instrument, and 573 data were measurable and analysed after the data screening process since 28 instruments were not fully completed. Four hundred and thirty-three $(75.6 \%)$ respondents were female, while the other 140 (24.4\%) respondents were males. Their age varied; $389(67.89 \%)$ respondents whose ages were below 35 years old and 184 $(32.11 \%)$ whose ages were 35 years old or above.

\section{Data Analysis}

Assessment on the data normality was done by measuring the Skewness, Kurtosis, as well as Histogram. We first applied the Skewness and Kurtosis for each domain for the 
normality test. Skewness and Kurtosis values should be in the range of -2 to 2 son, 2008). However, (Hair, Black, Babin, Anderson, Babin, \& Black, 2010) recommended the value from -1 to +1 for the Skewness threshold. The results of the Skewness of TPACK was informed to be appropriate (-.044 to .392). Similarly, the Kurtosis values were also in the range of -.226 to 1.494 that was within the suggested range (Hair et al., 2010). Using histogram that is a graph performing the real form the data distribution shape, we understand that the data were normally distributed since it performs a higher distribution in the middle than both edge sides (Chua, 2013).

The main examination of the pilot study data was conducted through Cronbach's alpha to see the reliability of the survey instruments (Pallant, 2016), EFA and CFA for the factor analysis assessment (Hair et al., 2010; Awang, 2012). For the EFA, some measurements were computed, Kaiser Meyer Olkin (KMO), Bartlett's Test of Sphericity, eigenvalue, communality, and factor extraction. The KMO value, greater than .500 , is considered appropriate while value, over .800, is highly satisfactory (Chua, 2014; Frohlich \& Westbrook, 2001). Bartlett's Test of Sphericity is significant at p < .050 (Hair et al., 2010). Factors, with an eigenvalue lower than 1.0, should be dropped from the factor list and communality value should not be less than .300 (Hair et al., 2010). The overall value of factor loading for each item over .400 is significant to confirm the meaningfulness of the questionnaire (Hair et al., 2010).

Afterward, the EFA was evaluated through CFA. The CFA model goodness-of-fit was examined using three indices: the Chi-Square Test $(\chi 2)$, the Root Mean Square Error of Approximation (RMSEA), and the Standardized Root Mean Square of Residual (SRMR). The relative goodness-of-fit indices are also strongly suggested for large sample sizes (Bentler \& Bonett, 1980). Two relative indices used were the Comparative Fit Index (CFI) and Tucker-Lewis Index (TLI). To achieve a fit model, the cut-off points were; the RMSEA $=\leq .080$ (Kelley \& Lai, 2011), the SRMR $=\leq .08(\mathrm{Hu} \&$ Bentler, 1999), for the TLI $=\geq .900$, and the CFI $=\geq .900$ (Hair et lal., 2010). Besides, the calculation of the chi-squared per degree of freedom and robust estimation was done (Hair et al., 2010; Kline, 2011).

Descriptive statistics (mean and standard deviation) were also utilized for the second research purposes, elaborating the perceptions of TPACK by Indonesian in-service EFL teachers. Finally, using a t-test, a significant difference of each domain was reported regarding the demographic information; gender, age (Hotelling, 1951). All process of this data analysis was done through IBM-SPSS 23 and AMOS 23.

\section{FINDINGS}

\section{TPACK Scale Validity and Reliability of Indonesian In-Service EFL Teachers}

For the EFA, the KMO value of the data was found to be highly satisfactory (.899) with Bartlett's Test of Sphericity was significant at $p=.000$. From the factor rotation using varimax, a seven-factor model was achieved with eigenvalues from 1.004 to 9.168 . The values of communality were from .506 to .814 that indicated no issue emerging in regard to the communality of the TPACK. Two items, PK4 and TPK1 were dropped 
because highly cross-loadings were detected. The Cronbach's alpha values were from .710 to 863 . The complete factor rotation can be seen in Table 2 .

Table 2

Factor Rotation, Communality, Eigenvalue, and Cronbach's Alpha

\begin{tabular}{|c|c|c|c|c|c|c|c|c|c|c|c|}
\hline \multicolumn{2}{|l|}{ Factor } & 1 & 2 & 3 & 4 & 5 & 6 & 7 & Communality & Eigenvalue & $\alpha$ \\
\hline \multirow[t]{6}{*}{ PK } & PK5 & .797 & & & & & & & .687 & 9.168 & .823 \\
\hline & PK7 & .735 & & & & & & & .634 & & \\
\hline & PK6 & .694 & & & & & & & .675 & & \\
\hline & PK1 & 679 & & & & & & & .657 & & \\
\hline & PK3 & .570 & & & & & & & .590 & & \\
\hline & PK2 & .538 & & & & & & & .634 & & \\
\hline \multirow[t]{5}{*}{ TPACK } & TPACK2 & & .738 & & & & & & 642 & 2.357 & .837 \\
\hline & TPACK4 & & .718 & & & & & & .606 & & \\
\hline & TPACK1 & & 693 & & & & & & .657 & & \\
\hline & TPACK5 & & 693 & & & & & & 687 & & \\
\hline & ТPACK3 & & .551 & & & & & & .662 & & \\
\hline \multirow[t]{3}{*}{ CK } & CK2 & & & .755 & & & & & .667 & 1.626 & .763 \\
\hline & CK3 & & & .731 & & & & & 681 & & \\
\hline & CK1 & & & .643 & & & & & .663 & & \\
\hline \multirow[t]{3}{*}{ PCK } & PCK2 & & & & .849 & & & & .779 & 1.477 & .863 \\
\hline & PCK3 & & & & .826 & & & & .777 & & \\
\hline & PCK1 & & & & .745 & & & & .815 & & \\
\hline \multirow[t]{3}{*}{ TCK } & TCK2 & & & & & .841 & & & .753 & 1.311 & .836 \\
\hline & TCK3 & & & & & .800 & & & .735 & & \\
\hline & TCK1 & & & & & .750 & & & .789 & & \\
\hline \multirow[t]{3}{*}{ TK } & TK2 & & & & & & .834 & & .702 & 1.267 & .822 \\
\hline & TK3 & & & & & & .758 & & .814 & & \\
\hline & TK1 & & & & & & .755 & & .750 & & \\
\hline \multirow[t]{3}{*}{ TPK } & TPK3 & & & & & & & .846 & .810 & 1.004 & .710 \\
\hline & TPK4 & & & & & & & .807 & .771 & & \\
\hline & TPK2 & & & & & & & .440 & .506 & & \\
\hline
\end{tabular}

CFA was conducted in order to verify the TPACK EFA. CFA can facilitate further evaluation regarding the fitness of the model in line with the structure of the factors proceeded through (Awang, 2012; Hair et al., 2010). The initial CFA process informed that while resulting in acceptable values of RMSEA (.079) and SRMR (.027), the other fit indices were not at the appropriate level showing a bad fit for the model (CFI $=.877$; TLI $=.854)$. To achieve good fit indices, three items were dropped one by one because low loading values were detected. The covariance was drawn (e13 to e15 and e19 to e20). The process was done until a satisfactory level of fit was achieved. The final results show a good fit indices for the CFA; RMSEA $=.068, \mathrm{SRMR}=.021 \mathrm{CFI}=.921$, and TLI $=.901$. The detail of the loading of CFA and arrows are drawn in Picture 2. 


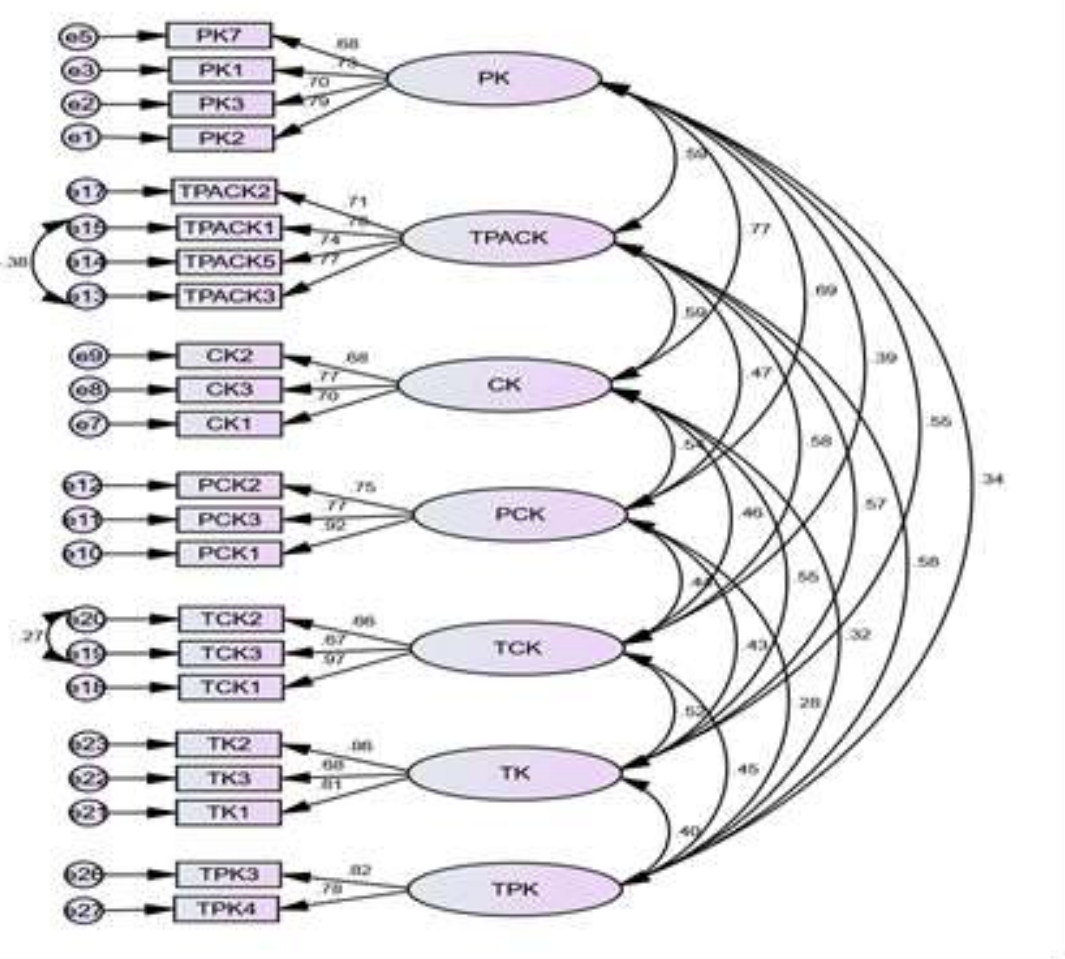

Figure 2

The CFA Result

Perceptions of TPACK by Indonesian In-Service EFL Teachers

All seven factors were highly correlated with each other. For example, the Pearson correlation between TK and CK was .420, TK and PK were 437. All correlation ranged from .323 to 547 (Table 3). The descriptive statistics are informed in detail for each item (Table 4). In general, PK obtained the highest overall score of the mean (3.753) while the lowest was for TK's $(\mathrm{M}=3.463)$.

Table 3

Correlation Matrix

\begin{tabular}{llllllll}
\hline & TK & CK & PK & TPK & PCK & TCK & TPACK \\
\hline TK & 1 & $.420^{* *}$ & $.437^{* *}$ & $.323^{* *}$ & $.341^{* *}$ & $.424^{* *}$ & $.491^{* * *}$ \\
CK & $.420^{* * *}$ & 1 & $.602^{* *}$ & $.241^{* *}$ & $.424^{* *}$ & $.359^{* *}$ & $.467^{* *}$ \\
PK & $.437^{* * *}$ & $.602^{* *}$ & 1 & $.276^{* *}$ & $.547^{* *}$ & $.345^{* *}$ & $.492^{* *}$ \\
TPK & $.323^{* * *}$ & $.241^{* *}$ & $.276^{* *}$ & 1 & $.202^{* *}$ & $.363^{* *}$ & $.466^{* *}$ \\
PCK & $.341^{* *}$ & $.424^{* *}$ & $.547^{* *}$ & $.202^{* *}$ & 1 & $.381^{* *}$ & $.394^{* *}$ \\
TCK & $.424^{* *}$ & $.359^{* *}$ & $.345^{* *}$ & $.363^{* *}$ & $.381^{* *}$ & 1 & $.472^{* *}$ \\
TPACK & $.491^{* *}$ & $.467^{* *}$ & $.492^{* *}$ & $.466^{* *}$ & $.394^{* *}$ & $.472^{* *}$ & 1 \\
\hline
\end{tabular}


Table 4

Descriptive Statistics

\begin{tabular}{|c|c|c|c|c|}
\hline & Items & Mean & SD & $\sum$ Mean \\
\hline \multirow[t]{3}{*}{$\overline{\mathrm{TKK}}$} & TK1 & 3.50 & .745 & 3.463 \\
\hline & TK2 & 3.58 & .689 & \\
\hline & TK3 & 3.30 & .683 & \\
\hline \multirow[t]{3}{*}{ CK } & CK1 & 3.71 & .722 & 3.658 \\
\hline & CK2 & 3.51 & .713 & \\
\hline & CK3 & 3.75 & .706 & \\
\hline \multirow[t]{4}{*}{ PK } & PK1 & 3.86 & 662 & 3.753 \\
\hline & PK2 & 3.76 & .639 & \\
\hline & PK3 & 3.74 & .622 & \\
\hline & PK7 & 3.75 & .675 & \\
\hline \multirow[t]{2}{*}{ TPK } & TPK3 & 3.55 & .542 & 3.612 \\
\hline & TPK4 & 3.55 & .548 & \\
\hline \multirow[t]{3}{*}{ PCK } & PCK1 & 3.63 & .722 & 3.637 \\
\hline & PCK2 & 3.62 & 680 & \\
\hline & PCK3 & 3.66 & 667 & \\
\hline \multirow[t]{3}{*}{ TCK } & TCK1 & 3.64 & .667 & 3.669 \\
\hline & TCK2 & 3.65 & .614 & \\
\hline & TCK3 & 3.72 & .604 & \\
\hline \multirow[t]{4}{*}{ TPACK } & TPACK1 & 3.52 & .683 & 3.594 \\
\hline & TPACK2 & 3.64 & .680 & \\
\hline & TPACK3 & 3.64 & 663 & \\
\hline & TPACK5 & 3.67 & .730 & \\
\hline
\end{tabular}

TPACK Differences in Perceptions According to Gender, Age and Teaching Experience

For all factors, TK to TPACK, perceptions female respondents were higher compared with the perceptions of male participants. Five factors, TK, CK, PK, PCK, and TPACK were detected to be statistically significant for the difference (Table 5); However, the difference was not statistically significant for two factors, TPK $(\mathrm{t}=2.923 ; \mathrm{p}=.040)$ and TCK $(\mathrm{t}=3.048 ; \mathrm{p}=.020)$. In term of age, most factors were statistically significantly different (Table 6). However, three factor factors, PK $(\mathrm{t}=1.146 ; \mathrm{p}=.252)$ and CK $(\mathrm{t}=$ $2.591 ; \mathrm{p}=.010)$ as well as PCK $(\mathrm{t}=2.228 ; \mathrm{p}=.026)$, were found to be not significant for the differences.

Table 5

T-test Results; Gender

\begin{tabular}{lllllll}
\hline Factor & $\begin{array}{l}\text { Female } \\
(\mathrm{N}=433)\end{array}$ & & $\begin{array}{l}\text { Male } \\
(\mathrm{N}=130)\end{array}$ & & t-statistics & p-value \\
\cline { 2 - 5 } & $\mathrm{M}$ & $\mathrm{SD}$ & $\mathrm{M}$ & $\mathrm{SD}$ & & \\
\hline TK & 3.511 & .578 & 3.312 & .665 & 3.425 & .001 \\
CK & 3.726 & .562 & 3.445 & .615 & 5.029 & .000 \\
PK & 3.828 & .496 & 3.618 & .570 & 4.205 & .000 \\
TPK & 3.585 & .469 & 3.446 & .545 & 2.923 & .040 \\
PCK & 3.693 & .584 & 3.462 & .660 & 3.947 & .000 \\
TCK & 3.708 & .516 & 3.548 & .614 & 3.048 & .020 \\
TPACK & 3.674 & .528 & 3.434 & .602 & 4.530 & .000 \\
\hline
\end{tabular}


Table 6

T-test Results; Age

\begin{tabular}{|c|c|c|c|c|c|c|}
\hline \multirow[t]{2}{*}{ Factor } & \multicolumn{2}{|c|}{$\begin{array}{l}<35 \text { years old } \\
(\mathrm{N}=389)\end{array}$} & \multicolumn{2}{|c|}{$\begin{array}{l}>35 \text { years old } \\
(\mathrm{N}=184)\end{array}$} & \multirow[t]{2}{*}{ t-statistics } & \multirow[t]{2}{*}{ p-value } \\
\hline & $\mathrm{M}$ & SD & $\mathrm{M}$ & SD & & \\
\hline TK & 3.554 & .590 & 3.270 & .587 & 5.398 & .000 \\
\hline CK & 3.614 & 606 & 3.750 & .537 & 2.591 & .010 \\
\hline PK & 3.760 & .526 & 3.813 & .471 & 1.146 & .252 \\
\hline TPK & 3.622 & 465 & 3.402 & .516 & 5.099 & .000 \\
\hline PCK & 3.602 & .626 & 3.723 & .570 & 2.228 & .026 \\
\hline TCK & 3.748 & .514 & 3.502 & .554 & 5.218 & .000 \\
\hline TPACK & 3.704 & .535 & 3.431 & .558 & 5.628 & .000 \\
\hline
\end{tabular}

\section{DISCUSSION}

The main purpose of this study was to establish a TPACK scale and to examine it's validity and reliability for the context of Indonesian in-service EFL teachers. Forty-one items of survey instruments were initiated, which were adapted from previous studies (Baser et al., 2016; Bostancioğlu \& Handley, 2018; Schmidt et al., 2009). Through the process of face and content validity (Lynn, 1986), 28 items of the questionnaire were validated and distributed to the respondents. Afterward, the data was conducted through EFA and CFA for factor analysis. The results from EFA yielded seven factors and were confirmed by the CFA. The goodness-of-fit for the model was considered satisfactory after the deletion and modification of the indices. The seven factors TK, CK, PK, PCK, TCK, and TPACK confirm the previous study findings (Schmidt et al., 2009; Baser et al., 2016). In contrast, Luik et al. (2018) reported Technology, Pedagogy, and Content as components of TPACK. Similarly, the result also opposes the findings of Chai et al., (2010) who reported a-four factor of TPACK (TK, CK, PK, TPACK), Shinas et al. (2013) informing 8 factors (TK, PK, CKM, CLS,CKL, CKSS, TPK, TPACK), Koh et al. (2010) reporting 5 factors (TK, CK, KP, KTT, and KCR), and Bostancioğlu and Handley (2018) with 6 factors (TK, CK, TPK, TCK, PCK, TPCK). Within this study context, the valid and reliable scale can be used to measure in-service EFL teachers TPACK in developing countries, especially in south East Asian region. For teacher educators, the scale can be used to analyse the needs of TPACK in designing their teaching training syllabus.

The second purpose of this study was to elaborate on the TPACK perceptions of Indonesian in-service EFL teachers. Similarly, with previous study (e.g. Baser et al., 2016; Bostancıoglu \& Handley, 2018; Chai et al., 2010; Luik et al., 2018), the respondent rated their perceptions higher than the neutral value (3). In our case, the respondents perceived PK as the strongest and TK as the weakest mean factor. This result contrasts previous studies. Chai et al. (2011) reported CK as the highest factor while Dong et al. (2015) informed CK as the weakest. The results of this study suggests that TK was perceived as the lowest could be due the low level of technology integration in Indonesian schools (Prasojo, Habibi, Yaakob, Mukminin, Haswindy, \& Sofwan, 2019). Indonesian teachers are still struggling in technology-based teaching. Their lack of knowledge might be the emergence some factors including lack of training 
and infrastructures, and lack of social supports from their leaders and peers (Habibi et al., 2019).

The third purpose of this study was to inform relationships between the components of TPACK and the teachers' demographics (gender and age). Comparing the perceptions of the male and female respondents, we reported that female perceptions of all domains of TPACK in this study were higher than that of the male participants'. It is in contrast to Luik et al. (2018) finding that informed that male perceptions were higher than females'. Similarly, Koh et al. (2015) reported elaborated that in all constructs related to technology, male teachers rated higher than female. Based on age, there were no significantly different reported between CK, PK, and PCK. However, statistical differences were found in TK, TPC, TCK, and TPACK. Partly, the finding is supported by the finding of Lin's et al. (2013) where TK was significantly different in term of age.

\section{CONCLUSION AND DIRECTION FOR FUTURE RESEARCH}

This study was a domain specific that can be applicable for Indonesian EFL teaching as Lin et al. (2013) stated that TPACK is more applicable with domain-specific field rather than the general field. TPACK has been introduced by Mishra and Koehler (2006); however, a few studies have been conducted in Indonesia as one of the developing countries. This study offers a new established scale to measure in-service EFL teachers TPACK for Indonesian context. We can inform that the assessed TPACK scale through EFA is valid and reliable. Therefore, it is useable for the context of the Indonesian EFL. The CFA confirmed the seven-factor model of TPACK domains. The highest perception in this study was achieved by PK, while the lowest was TK. Based on the findings of this study, the Indonesian teacher education programs for in-service teachers should focus on the element of technology in teaching. In addition, technology-based courses in the programs should be updated and taught sufficiently. Technological skill and knowledge for content and instruction are two main focus on this particular issue. They should benefits this result to design an appropriate approach for technological-based teacher training.

In terms of the study limitations, we should acknowledge that the scale applied in this study included an adapted-self-assessment instrument, which might not gain measurement the respondents' real knowledge; the respondents could over or underestimate their own knowledge for this survey. The respondents' numbers that were only 573 could also be a limitation in this study where a bigger number of respondents is more preferable. Further research on TPACK is recommended for researchers from developing countries, which are still limitedly available.

\section{ACKNOWLEDGMENT}

We thank the experts who provided insight and expertise that greatly assisted the development of the instrument of this study. We would like also to show our gratitude to all participants in this study for their time and effort.

\section{Funding Details}

The study was co-funded by Universitas Negeri Yogyakarta and Universitas Jambi, Indonesia. 


\section{REFERENCES}

Angeli, C., \& Valanides, N. (2009). Epistemological and methodological issues for the conceptualization, development, and assessment of ICT-TPCK: Advances in technological pedagogical content knowledge (TPCK). Computers \& Edu, 52, 154-168.

Awang, Z. (2012). Structural equation modeling using AMOS graphic. Universiti Teknologi MARA.

Baser, D., Kopcha, T. J., \& Ozden, M. Y. (2016). Developing a technological pedagogical content knowledge (TPACK) assessment for preservice teachers learning to teach English as a foreign language. Computer Assisted Lang. Lear., 29(4), 749-764.

Behr, D. (2017). Assessing the use of back translation: The shortcomings of back translation as a quality testing method. International Journal of Social Research Methodology, 20(6), 573-584.

Bernhardt, E.B. (2010). Teaching other languages. Edu. Practices Series, 20, 1-29.

Bostancioğlu, A., \& Handley, Z. (2018). Developing and validating a questionnaire for evaluating the EFL 'Total PACKage': Technological Pedagogical Content Knowledge (TPACK) for English as a foreign language (EFL). Computer Assisted Language Learning, 31(5-6), 572-598.

Chai, C. S., Koh, J. H. L., Tsai, C.-C., \& Tan, L. L. W. (2011). Modeling primary school pre-service teachers' technological pedagogical content knowledge (TPACK) for meaningful learning with information and communication technology (ICT). Computers \& Education, 57, 1184-1193.

Chua, Y. P. (2013). Mastering research statistics. McGraw-Hill Education.

Dong, Y., Chai, C. S., Sang, G. Y., Koh, J. H. L., \& Tsai, C. C. (2015). Exploring the profiles and interplays of pre-service and in-service teachers' technological pedagogical content knowledge (TPACK) in China. J. of Edu. Tech. \& Society, 18(1), 158-169.

Frohlich, M. T., \& Westbrook, R. (2001). Arcs of integration: an international study of supply chain strategies. Journal of Operations Management, 19(2), 185-200.

Golonka, E. M., Bowles, A. R., Frank, V. M., Richardson, D. L., \& Freynik, S. (2014). Technologies for foreign language learning: a review of technology types and their effectiveness. Computer Assisted Language Learning, 27(1), 70-105.

Goodwin, A. L., \& Kosnik, C. (2013). Quality teacher educators = quality teachers? Conceptualizing essential domains of knowledge for those who teach teachers. Teacher Development, 17(3), 334-346.

Graham, C. R., Borup, J., \& Smith, N. B. (2012). Using TPACK as a framework to understand teacher candidates' technology integration decisions. Journal of Computer Assisted Learning, 28, 530-546. 
Grossman, P. L. (1995). Teachers' knowledge. In L. W. Anderson (Ed.), International encyclopedia of teaching and teacher education (pp. 20-24). Oxford: Pergamon

Habibi, A., Mukinin, A., Riyanto, Y., Prasohjo, L. D., Sulistiyo, U., Sofwan, M., \& Saudagar, F. (2018). Building an online community: student teachers' perceptions on the advantages of using social networking services in a teacher education program. Turkish Online Journal of Distance Education, 19(1), 46-61.

Habibi, A., Yusop, F. D., \& Razak, R. A. (2019a). The role of TPACK in affecting preservice language teachers' ICT integration during teaching practices: Indonesian context. Education and Information Technologies, 25, 1929-1949. https://doi.org/10.1007/s10639-019-10040-2.

Habibi, A., Yusop, F. D., \& Razak, R. A. (2019b). The dataset for validation of factors affecting pre-service teachers' use of ICT during teaching practices: Indonesian context. Data in Brief, 28, 104875. https://doi.org/10.1016/j.dib.2019.104875.

Hair, J. F. J., Black, W. C., Babin, B. J., \& Anderson, R. E. (2010). Multivariate data analysis. New Jersey: Pearson education.

Halek, M., Holle, D., \& Bartholomeyczik, S. (2017). Development and evaluation of the content validity, practicability and feasibility of the Innovative dementia-oriented Assessment system for challenging behaviour in residents with dementia. BMC Health Services Research, 17(1), 554.

Hotelling, H. (1951). A generalized T test and measure of multivariate dispersion. Proceedings of the second Berkeley symposium on mathematical statistics and probability. The Regents of the University of California.

Howe, N., \& Strauss, W. (2007). The next 20 years: how customer and workforce attitudes will evolve. Harvard Business Review, 85(7-8), 41-52.

Hu, L. T., \& Bentler, P. M. (1999). Cut off criteria for fit indexes in covariance structure analysis: Conventional criteria versus new alternatives. Structural Equation Modelling: A Multidisciplinary Journal, 6(1), 1-55.

Kabilan, M. K., Ahmad, N., \& Abidin, M. J. Z. (2010). Facebook: An online environment for learning of English in institutions of higher education? The Internet and Higher Education, 13(4), 179-187.

Koh, J. H. L., Chai, C. S., \& Tsai, C. C. (2010). Examining the technological pedagogical content knowledge of Singapore pre-service teachers with a large-scale survey. Journal of Computer Assisted Learning, 26, 563-573

Lee, M. H., \& Tsai, C. C. (2010). Exploring teachers' perceived self-efficacy and technological pedagogical content knowledge with respect to educational use of the world wide web. Instructional Science, 38, 1-21.

Lin, T. C., Tsai, C. C., Chai, C. S., \& Lee, M. H. (2013). Identifying science teachers' perceptions of technological pedagogical and content knowledge (TPACK). Journal of Science Education and Technology, 22(3), 325-336. 
Luik, P., Taimalu, M., \& Suviste, R. (2018). Perceptions of technological, pedagogical and content knowledge (TPACK) among pre-service teachers in Estonia. Education and Information Technologies, 23(2), 741-755.

Lynn, M. R. (1986). Determination and quantification of content validity. Nursing research. 35(6), 382-386.

Mishra, P., \& Koehler, M. J. (2006). Technological pedagogical content knowledge: A framework for teacher knowledge. Teachers College Record, 108(6), 1017-1054.

Murray-Harvey, R. (2001). How teacher education students cope with practicum concerns. The Teacher Educator, 37(2), 117-132.

Pallant, J. (2016). SPSS survival manual: A step by step guide to data analysis using IBM SPSS, 6th Edn Crow's Nest. NSW: Allen \&Unwin.

Paulick, I., Großschedl, J., Harms, U., \& Möller, J. (2016). Preservice teachers' professional knowledge and its relation to academic self-concept. Journal of Teacher Education, 67(3), 173-182

Phillips, K. R., De Miranda, M. A., \& Shin, J. (2009). Pedagogical content knowledge and industrial design education. Journal of Technology Studies, 35(2), 47-55

Prasojo, L. D., Habibi, A., Yaakob, M. F. M., Mukminin, A., Haswindy, S., \& Sofwan, M. (2019). An explanatory sequential study on indonesian principals' perceptions on ICT integration barriers. Electronic Journal of e-Learning, 17(1).

Schmidt, D. A., Baran, E., Thompson, A. D., Mishra, P., Koehler, M. J., \& Shin, T. S. (2009). Technological pedagogical content knowledge (TPACK) the development and validation of an assessment instrument for preservice teachers. Journal of Research on Technology in Education, 42(2), 123-149.

Shinas, V. H., Yilmaz-Ozden, S., Mouza, C., Karchmer-Klein, R., \& Glutting, J. J. (2013). Examining domains of technological pedagogical content knowledge using factor analysis. Journal of Research on Technology in Education, 45(4), 339-360.

Shulman, L. S. (1986). Those who understand: Knowledge growth in teaching. Educational Researcher, 15(2), 4-14.

Teo, T., Sang, G., Mei, B., \& Hoi, C. K. W. (2019). Investigating pre-service teachers' acceptance of Web 2.0 technologies in their future teaching: a Chinese perspective. Interactive Learning Environments, 27(4), 530-546.

Thang, S. M., Lee, K. W., Murugaiah, P., Jaafar, N. M., Tan, C. K., \& Bukhari, N. I. A. (2016). ICT tools patterns of use among Malaysian ESL undergraduates. GEMA Online Journal of Language Studies, 16(1).

Voss, T., Kunter, M., \& Baumert, J. (2011). Assessing teacher candidates' general pedagogical/psychological knowledge: Test construction and validation. Journal of Educational Psychology, 103(4), 952. 